\title{
Photovoltaic flyback micro-inverter with power decoupling technique
}

\author{
Salam J. Yaqoob, Adel A. Obed \\ Electrical Engineering Technical College, Middle Technical University, Iraq
}

\begin{abstract}
Article Info
Article history:

Received Dec 25, 2018

Revised Feb 28, 2019

Accepted Mar 5, 2019

\section{Keywords:}

Low cost single-phase microinverter

Power decoupling (pd) circuit Improvement flyback microinverter

Dcm operation mode

ABSTRACT

This paper proposes a low-cost single-phase micro-inverter for grid-connected photovoltaic (PV) system. The lifetime of the conventional flyback microinverter is shortened, because lifetime of a large electrolyte capacitor is shortened. For this reason, the need for a large electrolyte capacitor is avoided by proposing power decoupling (PD) circuit. Dual advantages are achieved by proposed circuit, first high-power decoupling with small capacitances and other to protect the main MOSFET from spike voltage stress during turn off time without needing for additional a snubber circuit. Consequently, PD circuit is already used as a snubber circuit to absorb the leakage energy in the transformer, which may destroy the switch, and thus the voltage spike on the main MOSFET decreased. In addition, operating principle, modes, and control scheme of the proposed micro-inverter are discussed. As the simulation results, the input power ripple of the single-phase power fluctuation is under than $4 \%$, unity power factor (P.F) and the total harmonic distortion (THD) of the proposed inverter output current is less than 5\%. PSIM tool box is provided to simulate the proposed system and the simulation results are adequate.
\end{abstract}

Copyright $(2019$ Institute of Advanced Engineering and Science. All rights reserved.

\section{Corresponding Author:}

Salam J. Yaqoob,

Electrical Engineering Technical College,

Middle Technical University, Iraq

Email: engsalamjabr@yahoo.com

\section{INTRODUCTION}

In background, renewable energy, particularly solar energy is an important and promising as alternative electrical sources for electric power generation in recent years. Solar energy is plentiful, clean and free of pollution. It has the greatest availability among all the other energy sources. For this reason, solar energy is expected to take a main role in the world's electric power generation in the next decades [1-3]. This energy can be harvested by use of photovoltaic (PV) system. The PV systems can either be operated as stand-alone PV system or be connected to the utility grid. With rapidly declining cost of PV module, improvement in power electronics and government incentives towards PV system, it is imperative that penetration of PV systems on the utility grid would increases further especially on low and medium voltage grids [4]. The PV systems industry continued to go from strength to strength, recently recording many impressive developments and world-firsts [1-4]. Grid-connected micro-inverters as presents in Figure 1, with power level from 100 to 300W connected to a single PV module are representing the largest majority of the market for many reasons including; low cost of installation; increased system efficiency; improved power harvest; plug and play operation for the system; and reinforce flexibility and modularity. Mostly, a single stage flyback micro-inverter topology for decentralized grid-connected PV systems are used shown in Figure 2 [5-7]. In this topology, there are two main problems associated with it, first problem the maximum power extract from the PV module must be constant when the power flow to the utility grid is varying with time for maximizing power harvest operation. For this reason, instantaneous PV power mismatch with the AC power feeds to the grid is occurred [8]. Therefore, a 
large electrolytic capacitor has to be connected between the PV module and micro-inverter to balance this difference (availability power decoupling) as presented in reference [9].

Furthermore, shortening the lifetime of the electrolytic capacitors at high temperatures as in the summer reason such as in Iraq, cause shorted of a micro-inverter lifetime. Hence, in order to transferred a high power a large capacitance of an electrolyte capacitor is required. This lead to be increase the total cost of the micro-inverter and reduce the efficiency. The second problem, in flyback micro-inverter the energy stored in the leakage inductance of transformer cannot be transferred to the secondary side when main MOSFET turns off and this energy may result in a high voltage spike across the main MOSFET which may destroy the MOSFET if the spike is not damped as presented in reference [10]. Therefore, a snubber circuit is used to reducing the voltage spike of the main MOSFET. There are many types of the snubber circuits are used to protect the main MOSFET from this problem such as RC snubber circuit, RCD snubber circuit or active clamped circuit [5-10]. These circuits required additional parameters such as switches, capacitors, and resisters to build the snubber circuit, this lead to additional design cost for micro-inverter and decrease the overall efficiency due to the increasing of switching losses.

The proposed solution in this paper is solved the two problems in conventional flyback inverter with a new control strategy based on proposed power decoupling (PD) circuit. This technique can decoupling high maximum PV power to the micro-inverter that feeding to the grid with small capacitors, and protect the main MOSFET from the spike voltage by recycle the leakage energy of the transformer and absorbed it during this circuit without needing for additional a snubber circuit across the main MOSFET.

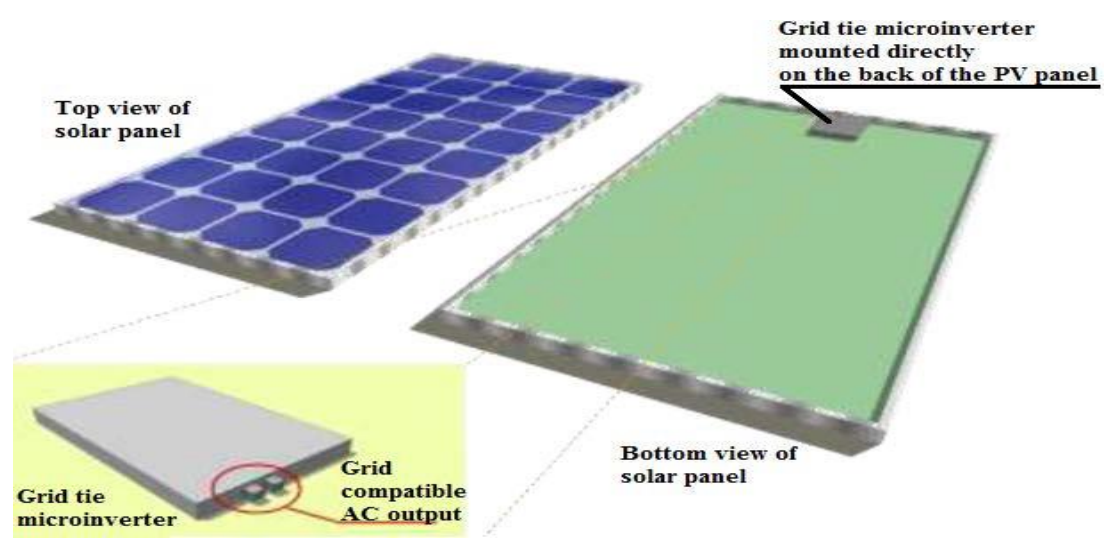

Figure 1. Instalation of single phase micro-inverter [1]

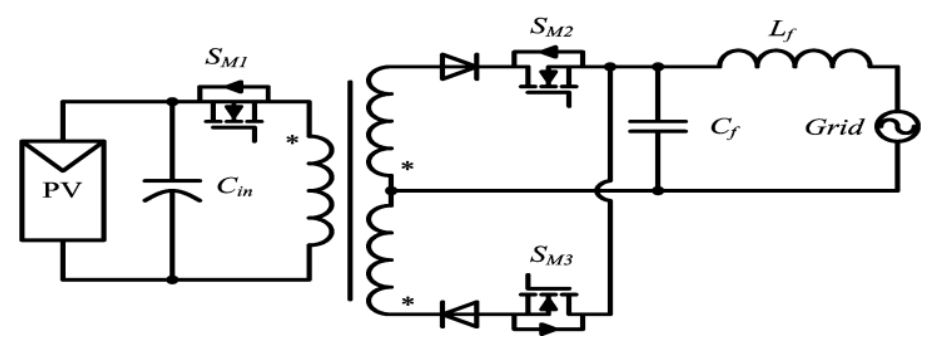

Figure 2. Conventional flyback micro-inverter topology [8]

\section{POWER DECOUPLING TECHNIQUES}

In a grid-connected micro-inverter as presented in Figure 3, the ac injected current to the utility grid, $\mathrm{i}_{\text {out }}(\mathrm{t})$ and the utility grid voltage, $\mathrm{v}_{\text {grid }}(\mathrm{t})$ are given by $[2,3]$ :

$$
\begin{aligned}
& \mathrm{i}_{\text {out }}(\mathrm{t})=\hat{\mathrm{I}}_{\text {out }} \sin (\omega \mathrm{t}+\varphi) \\
& \mathrm{v}_{\text {grid }}(\mathrm{t})=\widehat{\mathrm{V}}_{\text {grid }} \sin (\omega \mathrm{t})
\end{aligned}
$$

where $\omega$ is the grid frequency and $\varphi$ is the phase difference between the ac output current and the grid voltage, 
which it equal to zero at unity power factor. The output power $\mathrm{p}(\mathrm{t})$, is given by [2]:

$$
\mathrm{P}(\mathrm{t})=\frac{1}{2} \widehat{\mathrm{V}}_{\text {grid }} \hat{\mathrm{I}}_{\text {out }} \cos (\varphi)+\frac{1}{2} \widehat{\mathrm{V}}_{\text {grid }} \hat{\mathrm{I}}_{\text {out }} \cos (2 \omega \mathrm{t}+\varphi)
$$

at unity power factor (with zero phase shaft) this can be rewritten as follows:

$$
P(t)=\frac{1}{2} \widehat{V}_{\text {grid }} \hat{I}_{\text {out }}+\frac{1}{2} \widehat{V}_{\text {grid }} \hat{I}_{\text {out }} \cos (2 \omega t)
$$

the instantaneous output power in (4) consists of the constant average output power, $\mathrm{P}_{\text {avg }}(\mathrm{t})=\frac{1}{2} \widehat{\mathrm{V}}_{\text {grid }} \hat{\mathrm{I}}_{\mathrm{out}}$, and pulsation output power $\mathrm{P}_{\mathrm{oac}}(\mathrm{t})=\frac{1}{2} \widehat{\mathrm{V}}_{\text {grid }} \hat{\mathrm{I}}_{\text {out }} \cos (2 \omega \mathrm{t})$, which is a time varying with twice grid frequency oscillation [10,11]. However, decoupling capacitor is used to maintain power balance and minimize the ripple effect at output power of PV system. The decoupling capacitor value will be calculated based on the energy amount that has to be stored in this capacitor, as shown follows [12-14]:

$$
C_{\text {in }}=\frac{P_{P V}}{2 \pi f V_{P V} \Delta_{V}}
$$

where $\mathrm{f}$ is grid frequency, $\mathrm{P}_{\mathrm{PV}}$ is the output power from $\mathrm{PV}$ system, $\mathrm{V}_{\mathrm{PV}}$ is the output voltage of PV system, which mean voltage across the capacitor, $\Delta_{\mathrm{V}}$ is the voltage ripple.

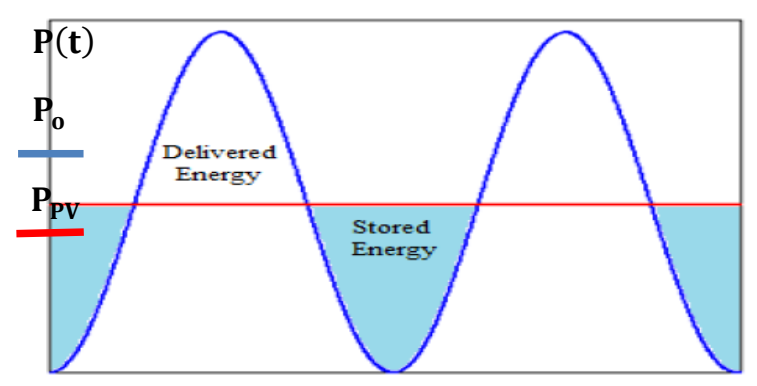

Figure 3. The overall power by the decoupling circuit [10]

Moreover, power decoupling techniques depend on the type of micro-inverter topology single- stage or multi-stage inverters [15-18]. Furthermore, in single-stage micro-inverter as presented in Fig.4, the capacitor of power decoupling has been placed across PV input side.

On the other hand, multi-stage micro-inverter such as DC-AC-AC, DC-AC-DC-AC, and DC-DC-AC the decoupling capacitor is selected according to the procedure that has to be discussed in reference [2], there are three decoupling techniques based on the location of the capacitor can be classified: (1) PV side decoupling capacitor (2) DC link decoupling capacitor (3) and AC side decoupling capacitor.

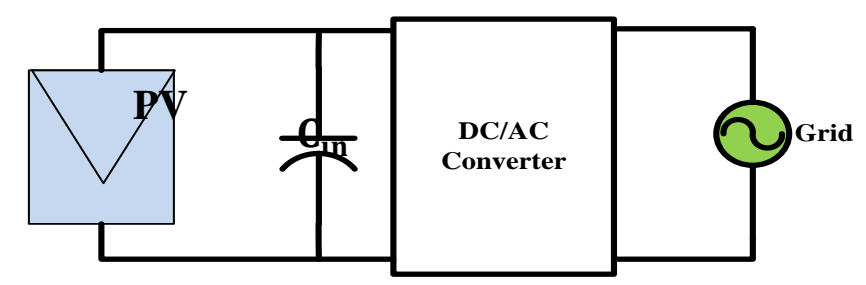

Figure 4. Single-stage micro-inverter

\section{PROPOSED MICRO-INVERTER TOPOLOGY}

The proposed micro-inverter with PD circuit is presented in Figure 5. It consists of PV module; primary side with two MOSFET switches, $\mathrm{S}_{\mathrm{PV}}$ and $\mathrm{S}_{\mathrm{PD}}$; protection diode, $\mathrm{D}_{\mathrm{PV}}$; flyback center-tap transformer, $\mathrm{T}$; a PV input capacitor, $\mathrm{C}_{\mathrm{in}}$; power decoupling capacitor, $\mathrm{C}_{\mathrm{PD}}$; ac MOSFET switches at secondary side $\mathrm{S}_{\mathrm{AC} 1}$ and $\mathrm{S}_{\mathrm{AC} 2}$; blocking diodes, $\mathrm{D}_{1}$ and $\mathrm{D}_{2}$; and ac C-L filter $\mathrm{C}_{\mathrm{f}}$ and $\mathrm{L}_{\mathrm{f}}$. The PV module is used for the input dc 
source of this micro-inverter, and the ac utility grid is connected as the output load. The proposed microinverter circuit operates in discontinuous conduction mode (DCM) to reduce the control complexity. The operating principle of proposed micro-inverter is depending on the energy storage in the magnetizing inductance of transformer during the on time $\left(\mathrm{T}_{\mathrm{on}}\right)$ interval of main switch at primary side $\mathrm{S}_{\mathrm{PV}}$, and discharge of this energy to the output at off time interval $\left(\mathrm{T}_{\text {off }}\right)$. The feature of DCM that all energy stored in the magnetizing inductance is transferred to an output circuit before the another on time period occurs. In proposed micro-inverter by using a PD circuit, the maximum power from PV module is decoupling to the micro-inverter with a little ripple content. Also, using PD circuit the voltage spike generated the conventional flyback inverter is removed and the turn off loss of the main MOSFET, $S_{\mathrm{PV}}$ is reduced. The unfolding switches, $\mathrm{S}_{\mathrm{AC} 1}$ and $\mathrm{S}_{\mathrm{AC} 2}$ in secondary side operates with $50 \mathrm{~Hz}$ like as utility grid frequency for grid connection. The output C-L filter is used for reducing the harmonic component in ac output current that feds to the grid.

\section{MODS OF OPERATION FOR PROPOSED MICRO-INVERTER TOPOLOGY}

The operation circuit of micro-inverter topology depends on the PD circuit consists of two state: (i) charging operation state; and (ii) discharging operation state. In PD circuit, the power decoupling capacitor $\left(\mathrm{C}_{\mathrm{PD}}\right)$ work as a load in charging mode and as a source in the discharging mode.

Furthermore, depends on the value of the output power, $\mathrm{P}_{\mathrm{o}}$, as presented in Figure 3, when $\mathrm{P}_{\mathrm{o}}<\mathrm{P}_{\mathrm{PV}}$, the circuit will be operating in charging state, where the extra energy will be stored in this capacitor $\left(\mathrm{C}_{\mathrm{PD}}\right)$. On the other hand, when $\mathrm{P}_{\mathrm{o}}>\mathrm{P}_{\mathrm{PV}}$, the power decoupling capacitor will be discharging energy into the magnetizing inductance of the transformer and transferring the output power to the grid.

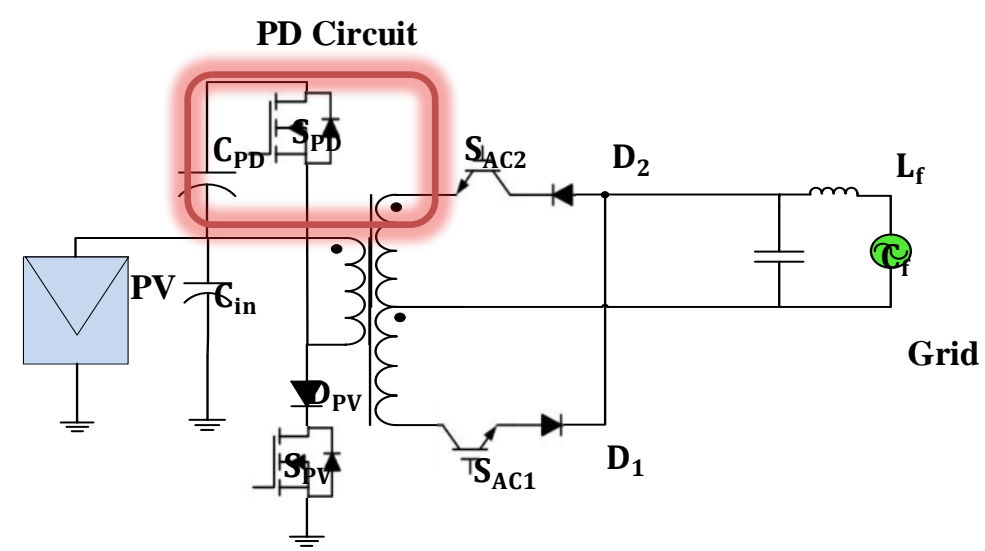

Figure 5. The proposed circuit configuration of micro-inverter topology

Mode I: $\mathrm{S}_{\mathrm{PV}}$ is turned on the PV energy will be stored in magnetizing inductance of transformer, where the primary current $\left(I_{p}\right)$ ramps up until it reaches to peak value, $I_{p k}$ which can be written as [3, 12]:

$$
\mathrm{I}_{\mathrm{pk}}=\frac{\mathrm{V}_{\mathrm{PV}} \mathrm{T}_{\mathrm{on}}}{\mathrm{L}_{\mathrm{m}}}=\frac{\mathrm{V}_{\mathrm{PV}} \mathrm{DT}}{\mathrm{L}_{\mathrm{m}}}
$$

where $\mathrm{L}_{\mathrm{m}}$ is the magnetizing inductance, $\mathrm{D}$ is the duty ratio, $\mathrm{T}_{\mathrm{s}}$ is the switching time period. Due to inductor volt-seconds balance and to avoid the continuous condition mode operation the duty ratio should be given as [4]:

$$
\mathrm{D}_{\max }<\frac{\widehat{\mathrm{V}}_{\text {grid }}}{\left(\mathrm{N} \mathrm{V}_{\mathrm{PV}}+\widehat{\mathrm{V}}_{\text {grid }}\right)}
$$

where $\mathrm{N}$ is the transformer ratio, $\mathrm{V}_{\text {grid }}$ is the peak grid voltage.

The peak primary current value varies with time and has a rectifed sin waveform due to the sinosdal modulation as will be show later in simulation results.

When the primary current reaches to the peak value, $\mathrm{I}_{\mathrm{pk}}, \mathrm{S}_{\mathrm{PV}}$ is turned off. During this mode, all other switches are off and the energy of transformer will have converted to decoupling capacitor as presented in 
Figure 6 (a). However, from equation (6) and (7), to maintain in DCM operation condition the magnetizing inductance of transformer must be limited as follows [10]:

$$
\mathrm{L}_{\mathrm{m}}<\frac{1}{2}\left(\frac{\mathrm{V}_{\mathrm{PV}}}{\widehat{\mathrm{V}}_{\text {grid }}}\right)^{2} \frac{\mathrm{D}_{\mathrm{max}}^{2} \mathrm{~V}_{\mathrm{g}, \mathrm{rms}}^{2}}{\mathrm{P}_{\mathrm{o}} \mathrm{f}_{\mathrm{s}}}
$$

Mode II: When the $S_{P V}$ is turned off, the primary current is released as, $I_{P D}$, flows across decoupling capacitor, $\mathrm{C}_{\mathrm{PD}}$, through the body diode of switch, $\mathrm{S}_{\mathrm{PD}}$, as shown in Figure 6 (b). Afterthought, this current decreases towards zero. Since, the direction of current, $\mathrm{I}_{\mathrm{PD}}$, is changed and the $\mathrm{S}_{\mathrm{PD}}$ is turn on with one of the AC output side. The switches, $\mathrm{S}_{\mathrm{AC} 1}$ or $\mathrm{S}_{\mathrm{AC} 2}$ will be turned on in zero voltage switching (ZVS), and the power will be transferred to output as shown in Figure 6 (c), the RMS value of output current approximately equal to average value of secondary current in every switching period after filtering as will be shown later in simulation results.
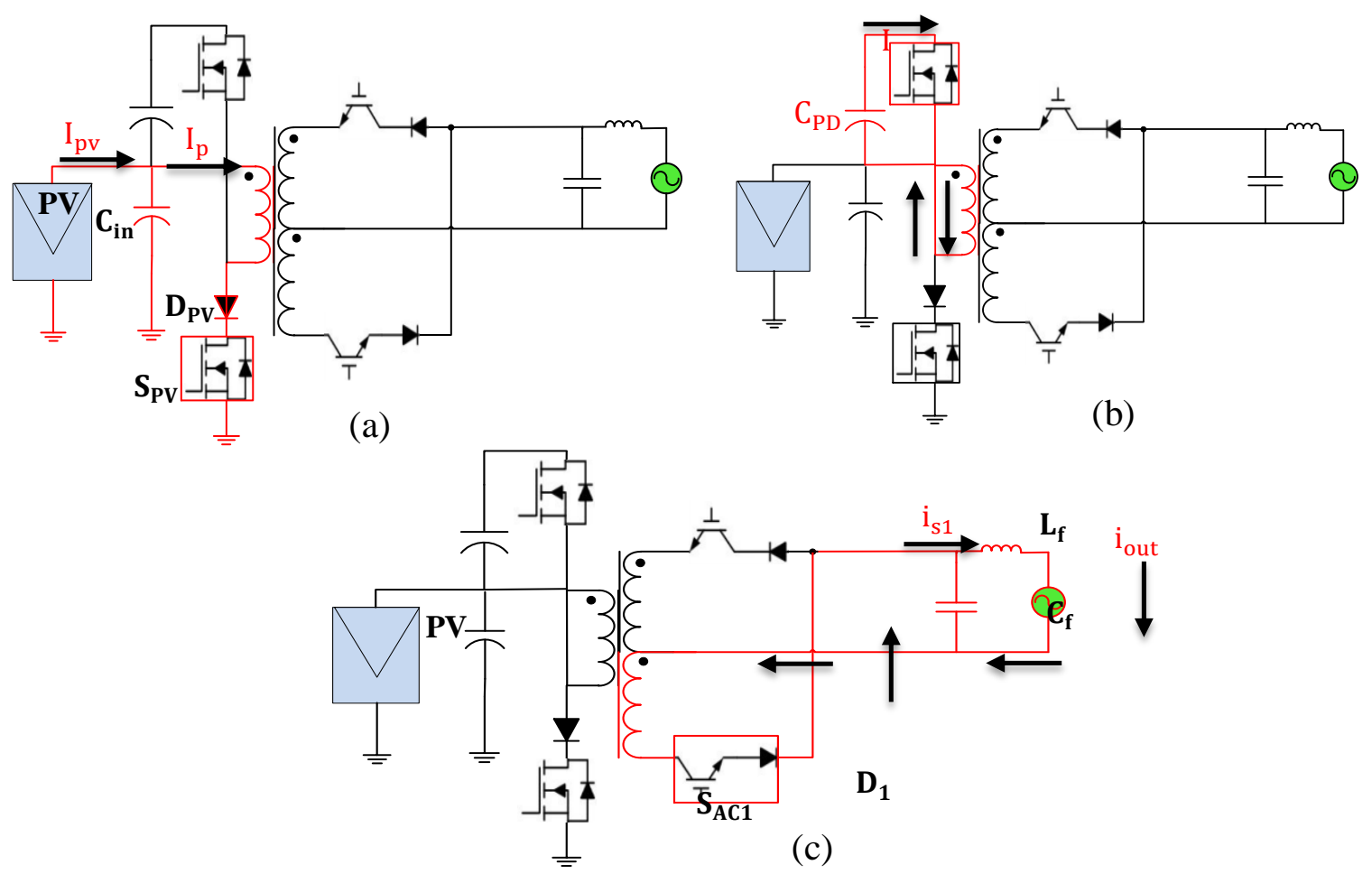

Figure 6. Modes of operation for micro-inverter topology at half grid period

\section{A PROPOSED CONTROL STRATEGY AND MAXIMUM POWER POINT TRACKING FOR MICRO-INVERTER TOPOLOGY}

As presented in Figure 7, the control block diagram includes MPPT for proposed micro-inverter topology, in this diagram, the well-known perturbation and observation (P\&O) method for MPPT is used. The main advantage of this method is the simplicity, where the voltage, $\mathrm{V}_{\mathrm{PV}}$ and current, $\mathrm{I}_{\mathrm{PV}}$ of the $\mathrm{PV}$ system are sensed, then by decreasing or increasing the PV module current, the PV output power also decreasing or increasing, and then compared with previous value to achieve MPPT operating point with varied solar insulation and temperature. Since, constant input dc current, $\mathrm{I}_{\mathrm{MP}}^{*}$ from PV system is adjusted by MPPT. A proportional-integral controller (PI controller) is the most widely used in the process control circuit due to its simple and easy parameter adjusting. Since, the PI controller used to calculate an "error" value as the difference between a measured PV system current, $\mathrm{I}_{\mathrm{PV}}$ and a desired maximum current of PV system from MPPT method, $I_{M P}^{*}$. Further that, trigger signal, $V_{\text {trg }}$ which has switching frequency, $\mathrm{f}_{\mathrm{s}}$ is used to enable the turn on process of $\mathrm{S}_{\mathrm{PV}}$. If the primary current reach to it is peak value, $\mathrm{I}_{\mathrm{pk}}$ the main switch, $\mathrm{S}_{\mathrm{PV}}$ is turn off. On other hand, the sub switch, $\mathrm{S}_{\mathrm{DC}}$ become turn off when the decoupling capacitor current, $\mathrm{I}_{\mathrm{DC}}$ reach to peak value that compared with secondary transformer current reference, $\mathrm{i}_{\mathrm{s} 1}^{*}$ which is sinewave rectifier waveform. 
The two switches side the grid, $\mathrm{S}_{\mathrm{AC} 1}$ and $\mathrm{S}_{\mathrm{AC} 2}$ are turns on depending on the grid period (20ms), $\mathrm{S}_{\mathrm{AC} 1}$ turns on during the positive half cycle, while the other $\mathrm{S}_{\mathrm{AC} 2}$ turns on during the negative half cycle, every switch conduct for $10 \mathrm{~ms}$.

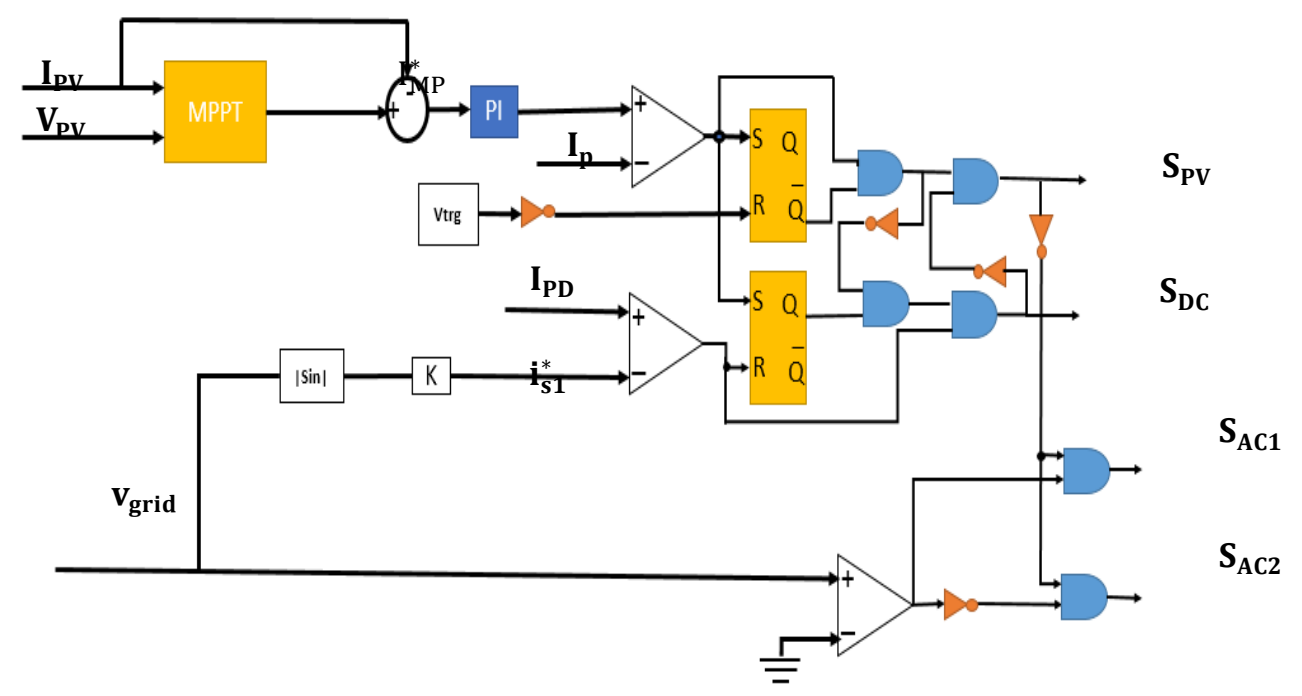

Figure 7. The proposed control block diagram

\section{ANALYSIS OF SIMULATION RESULTS}

To verify the validity of the proposed micro-inverter, a simulation study was carried out by PSIM software as shown in Figure 8, based on the system parameters as presented in Table 1. Figures 9-15 include the main waveforms of the proposed micro-inverter under different solar insulation( $G$ ) and cell temperature (T). Figure 9 shows the output power from the PV module with a little ripple about $\Delta_{\text {ripple }}=4 \%$, due to good performance of the PD circuit for solar iradiation, $\mathrm{G}=700 \mathrm{~W} / \mathrm{m}^{2}$ and ambinet temperature, $\mathrm{T}=$ $20^{\circ} \mathrm{C}$.

Figure 10 shows the drain-source voltage $\left(\mathrm{V}_{\mathrm{ds}}\right)$ for the main MOSFET, $\mathrm{S}_{\mathrm{PV}}$, in conventional flyback inverter, this voltage may be cause damage the main MOSFET due to it has a spike voltage of $\mathrm{V}_{\text {spike }}=170 \mathrm{~V}$. The spike voltage on the main MOSFET, decreases by the proposed micro-inverter as presented in Figure 11, the spike voltage decreased to $\mathrm{V}_{\text {spike }}=40 \mathrm{~V}$. Figure 12 and 13 depict the instantaneous input power and instantaneous output power which has double grid frequency ripple in conventional flyback inverter and the proposed micro-inverter, respectively, for solar iradiation, $\mathrm{G}=700 \mathrm{~W} / \mathrm{m}^{2}$ and ambinet temperature, $\mathrm{T}=20^{\circ} \mathrm{C}$. Figure 14 shows the operating currents in proposed micro-inverter, include the primary current which has a shape like a rectified sin due to the sinusoidal modulation, it has the peak value $\hat{\mathrm{I}}_{\mathrm{p}}=32 \mathrm{~A}$, and output ac current injected to the grid before filtering which combined of the two current of secondary winding transformer, $\mathrm{i}_{\mathrm{s} 1}$ and $i_{\mathrm{s} 2}$. Figure 15 a pure sinusoidal output current feeding to the grid, with low total harmonic distortion (THD) and unity power factor (P.F), is achieved which it almost in-phase with the utility grid voltage. Figure15-a shows the output current feeding to the grid for solar iradiation $\mathrm{G}=700 \mathrm{~W} / \mathrm{m}^{2}$ and ambinet temperature $\mathrm{T}=$ $20^{\circ} \mathrm{C}$. Figure 15-b shows the output current feeding to the grid for $\mathrm{G}=600 \mathrm{~W} / \mathrm{m}^{2}$ and ambinet temperature $\mathrm{T}=30^{\circ} \mathrm{C}$. Figure $15-\mathrm{c}$ shows the output current feeding to the grid solar iradiation $\mathrm{G}=400 \mathrm{~W} / \mathrm{m}^{2}$ and ambinet temperature $\mathrm{T}=40^{\circ} \mathrm{C}$. The output current feeding to the grid, $\mathrm{i}_{\text {out,rms }}$ is approximately proportional to the solar irradiance, a high output current obtained in high irradiance, then good values of THD and P.F are achieved. With use small capacitances in dc input side, the efficiency is less effected by increasing the temperature, and minimum turn off losses on the main MOSFET increasing in the efficiency. Different simulation results with different solar irradiance and cell temperature are carried out to show the performance of the proposed inverter. 
Table 1. Simulation parameters for proposed micro inverter

\begin{tabular}{lcc}
\hline \multicolumn{1}{c}{ Parameter } & Value & Unit \\
\hline PV module voltage $\left(\mathrm{V}_{\mathrm{PV}}\right)$ & $33-38$ & $\mathrm{~V}$ \\
Maximum output power $\left(\mathrm{P}_{\mathrm{o}}\right)$ & 150 & $\mathrm{~W}$ \\
Input capacitor $\left(\mathrm{C}_{\text {in }}\right)$ in conventional inverter & 7720 & $\mu \mathrm{F}$ \\
Decoupling capacitor $\left(\mathrm{C}_{\mathrm{PD}}\right)$ & 60 & $\mu \mathrm{F}$ \\
Input capacitor $\left(\mathrm{C}_{\text {in }}\right)$ in proposed inverter & 30 & $\mu \mathrm{F}$ \\
Switching frequency $\left(\mathrm{f}_{\mathrm{s}}\right)$ & 20 & $\mathrm{kHz}$ \\
Transformer turn ratio $(\mathrm{N})$ & 5 & - \\
Magnetizing inductance $\left(\mathrm{L}_{\mathrm{m}}\right)$ & 38 & $\mu \mathrm{H}$ \\
Maximum duty cycle $(\mathrm{D})$ & 0.65 & - \\
AC output inductor filter $\left(\mathrm{L}_{\mathrm{f}}\right)$ & 3 & $\mathrm{mH}$ \\
AC output capacitor filter $\left(\mathrm{C}_{\mathrm{f}}\right)$ & 2 & $\mu \mathrm{F}$ \\
\hline
\end{tabular}
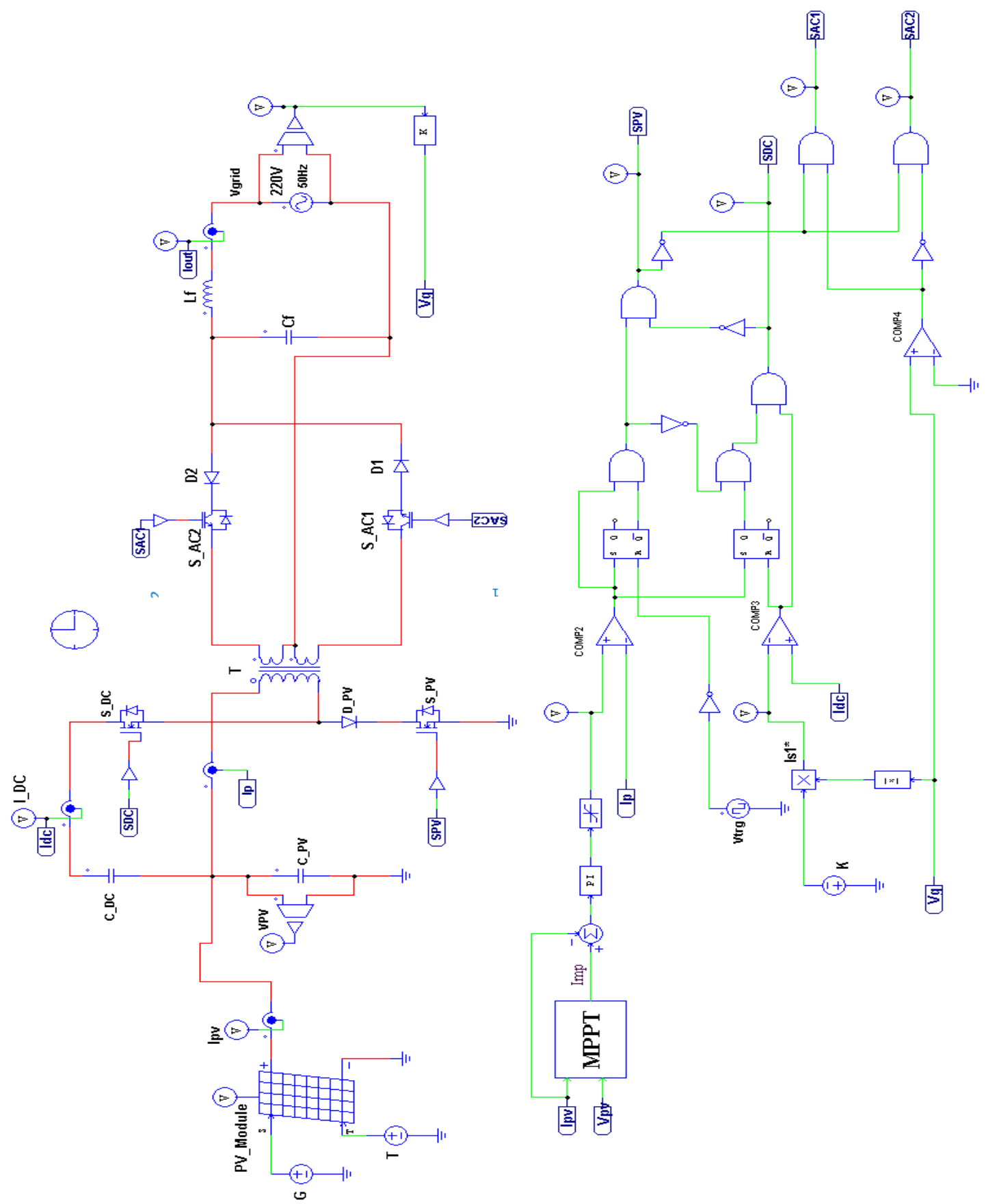

Figure 8. The proposed flyback micro-inverter with PD circuit by using PSIM 


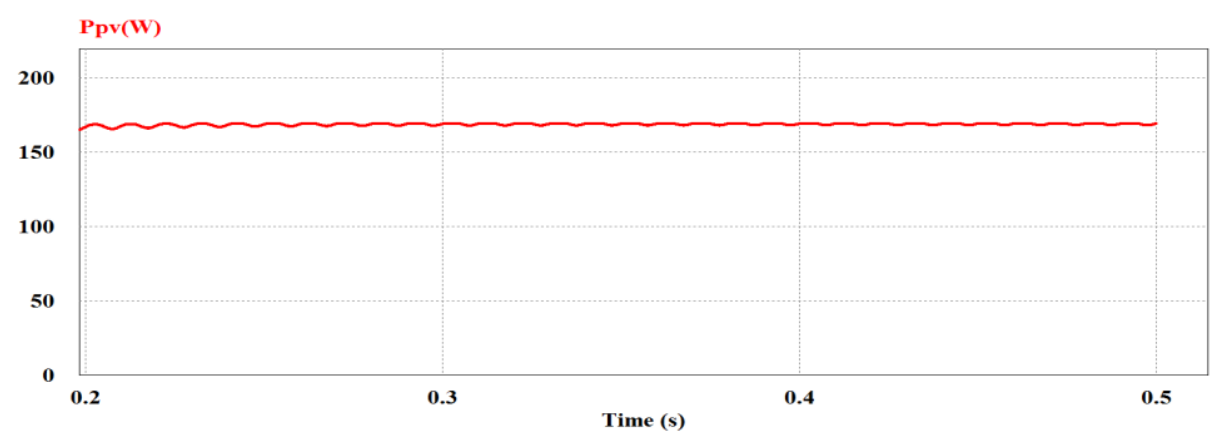

Figure 9. Output power form PV module, $\mathrm{P}_{\mathrm{PV}}=160 \mathrm{~W}$

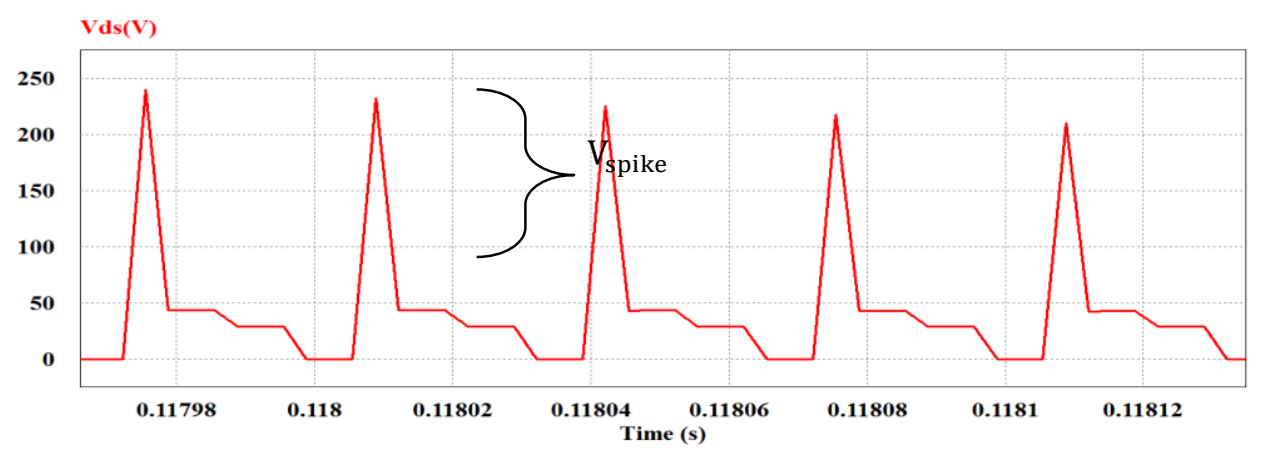

Figure 10. The Drain-Source voltage $\left(\mathrm{V}_{\mathrm{ds}}\right)$ of main MOSFET $\mathrm{S}_{\mathrm{PV}}$ for conventional flyback inverter

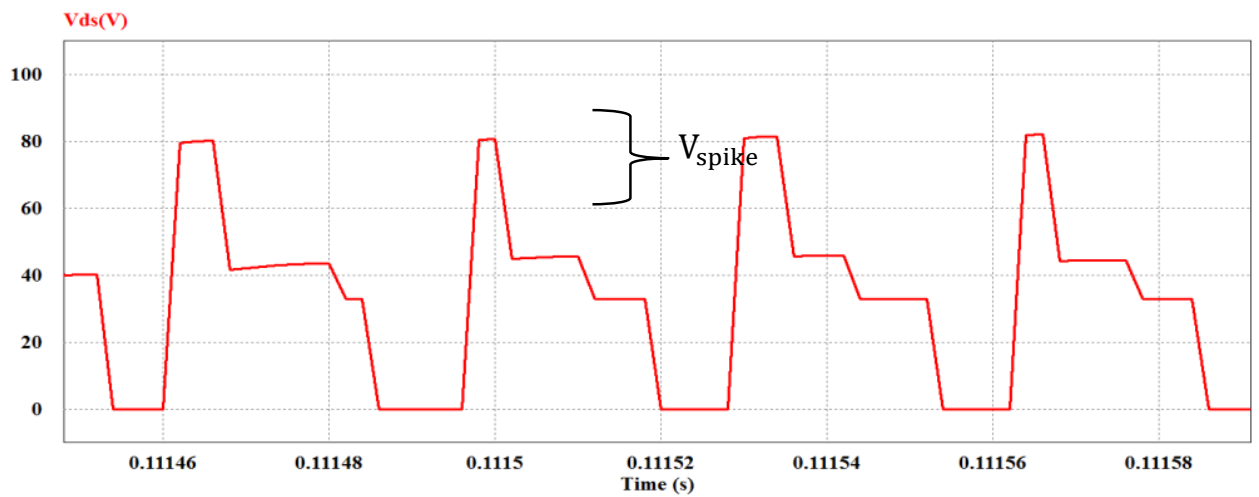

Figure 11. The Drain-Source voltage $\left(\mathrm{V}_{\mathrm{ds}}\right)$ of main MOSFET $\mathrm{S}_{\mathrm{PV}}$ for proposed micro-inverter

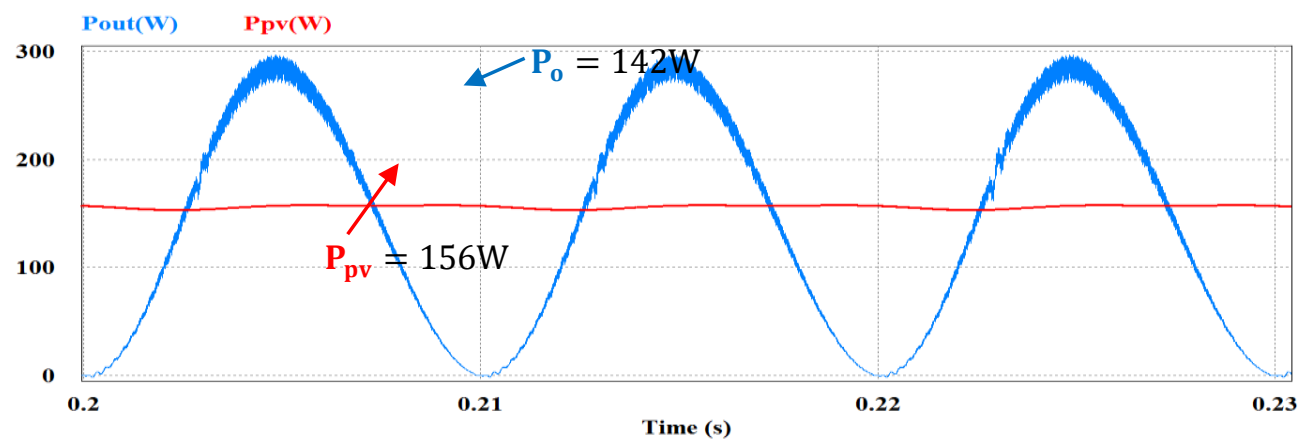

Figure 12. The overall power by the decoupling circuit in conventional flyback inverter 


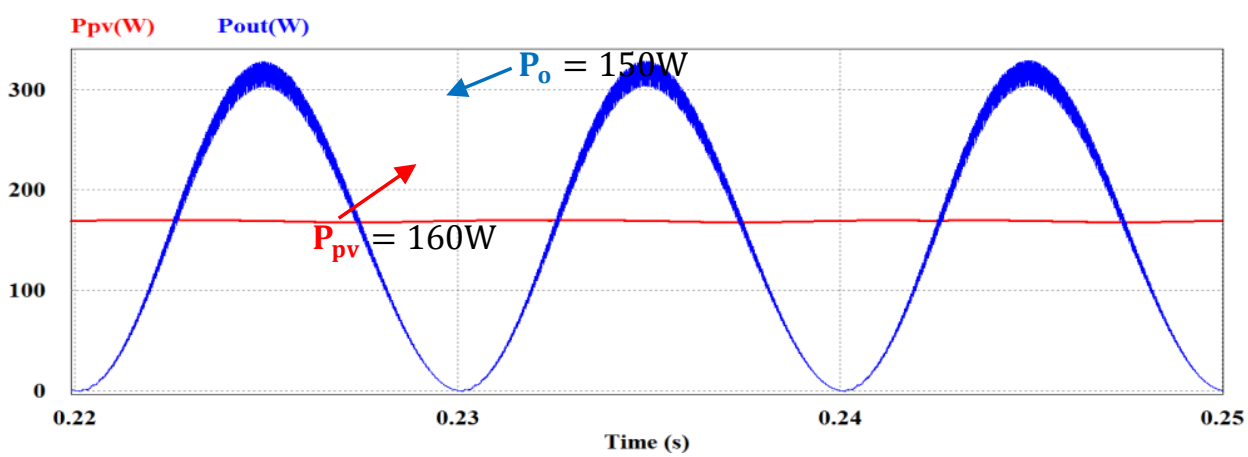

Figure 13. The overall power by the decoupling circuit in proposed micro-inverter.I
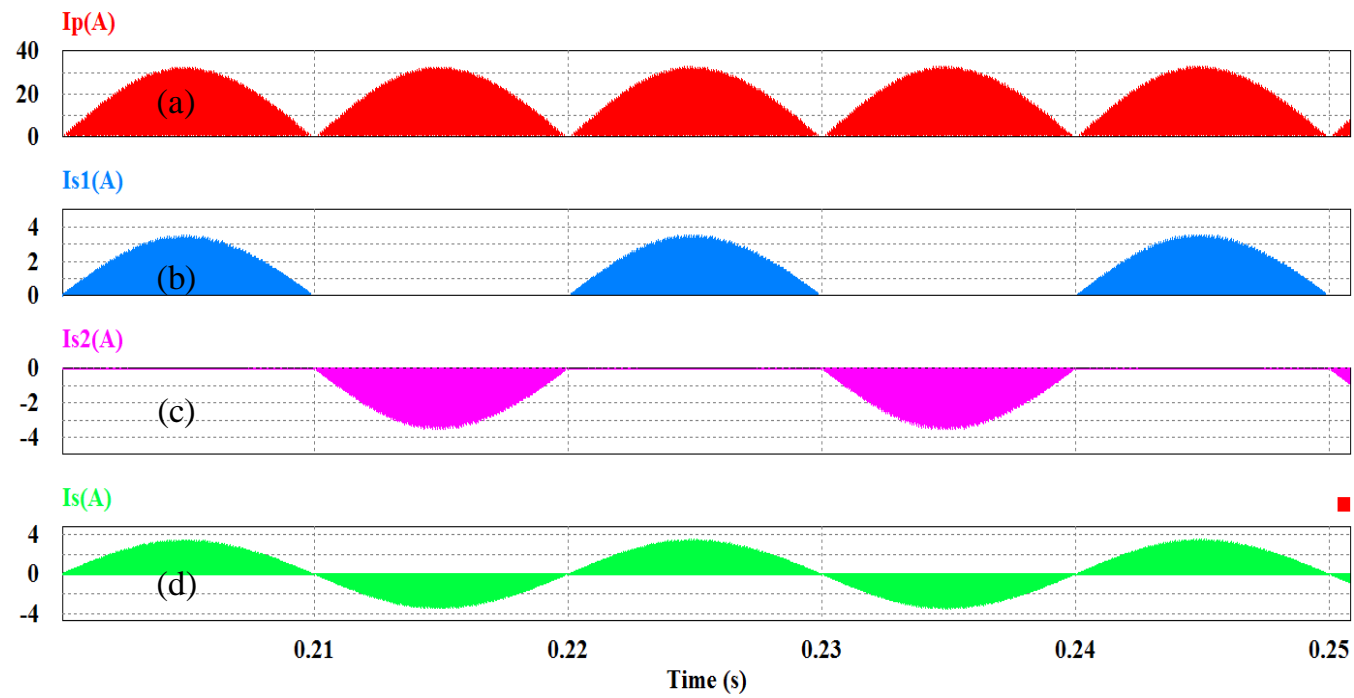

Figure 14. Operating currents in proposed micro-inverter. (a) The primary current, $I_{P}$ (b) The first secondary current, $I_{s 1}$. (c) The second secondary current $I_{s 2}$, (d) The total secondary current, $I_{s}$

Table 2. Different simulation results with different solar irradiance and temperature for proposed microinverter

\begin{tabular}{cccccccl}
\hline $\begin{array}{c}\mathbf{G} \\
\left(\mathbf{W} / \mathbf{m}^{2}\right)\end{array}$ & $\begin{array}{c}\mathbf{T} \\
\left({ }^{\circ} \mathbf{C}\right)\end{array}$ & $\begin{array}{c}\mathbf{P}_{\mathbf{p v}} \\
(\mathbf{W})\end{array}$ & $\begin{array}{c}\mathbf{P}_{\mathbf{o}} \\
(\mathbf{W})\end{array}$ & $\begin{array}{c}\mathbf{i}_{\text {out,rms }} \\
(\mathbf{A})\end{array}$ & $\begin{array}{c}\text { THD } \\
(\%)\end{array}$ & $\mathbf{P . F}$ & $\begin{array}{c}\mathbf{\eta} \\
(\%)\end{array}$ \\
\hline 750 & 30 & 165 & 156 & 0.87 & 2.7 & 0.99 & 94.4 \\
650 & 25 & 151 & 139 & 0.6 & 3.3 & 0.98 & 92 \\
550 & 35 & 114 & 103 & 0.47 & 3.6 & 0.97 & 90.3 \\
500 & 34 & 95 & 85 & 0.4 & 3.7 & 0.966 & 90 \\
490 & 44 & 94 & 84 & 0.37 & 3.8 & 0.96 & 89.8 \\
400 & 32 & 62 & 55 & 0.25 & 3.9 & 0.957 & 89 \\
320 & 18 & 37 & 33 & 0.17 & 4 & 0.953 & 88.8 \\
260 & 43 & 27.5 & 24 & 0.11 & 4.2 & 0.94 & 88.6 \\
200 & 33 & 7 & 5.8 & 0.07 & 4.25 & 0.92 & 87.5 \\
\hline
\end{tabular}



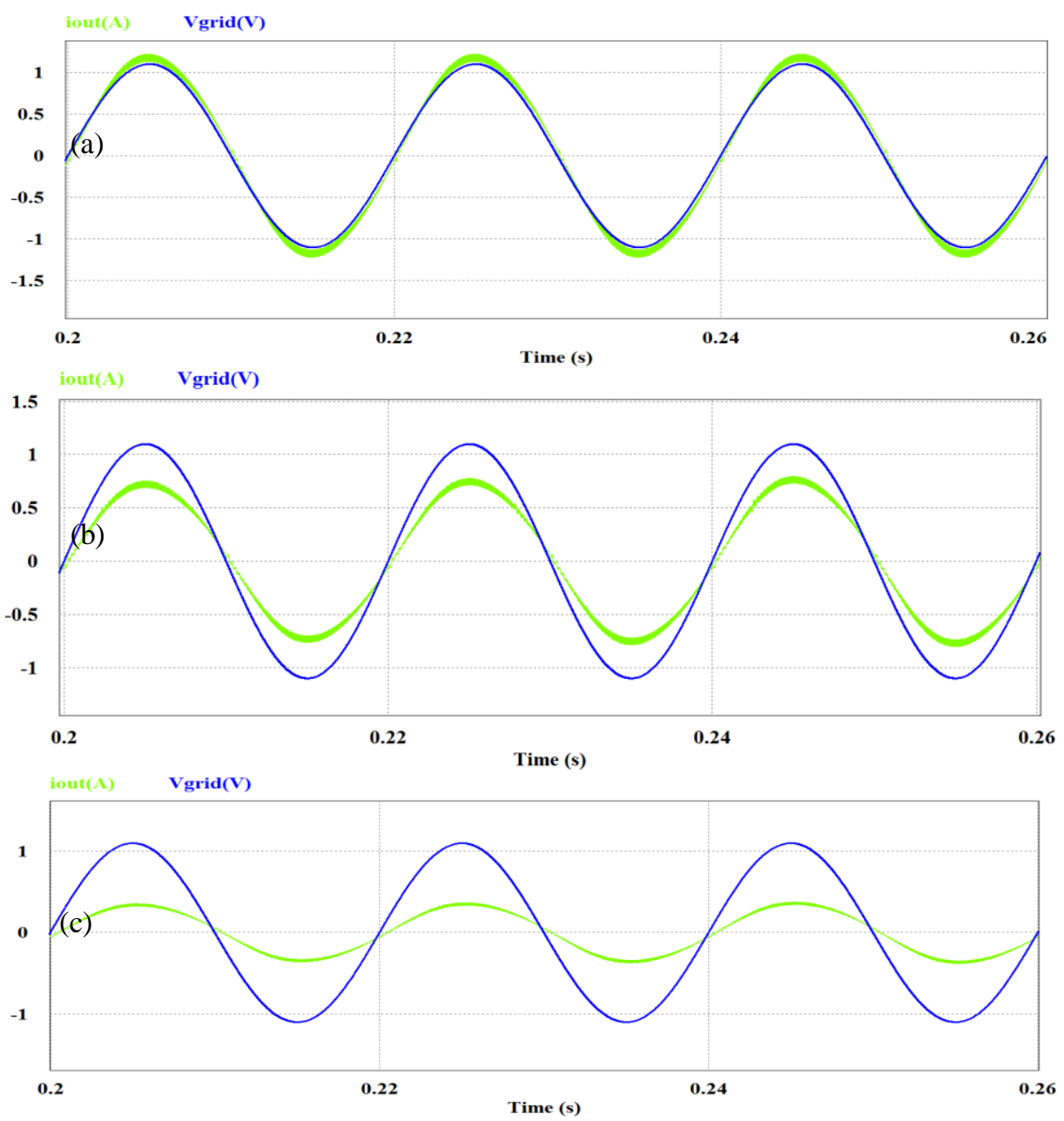

Figure 15. The output current feeding to the grid with grid voltage divided by 200 . (a) $i_{\text {out,rms }}=0.77 \mathrm{~A}$ (b)

$$
\mathrm{i}_{\text {out }, \text { rms }}=0.54 \mathrm{~A}(\mathrm{c}) \mathrm{i}_{\text {out }, \mathrm{rms}}=0.25 \mathrm{~A}
$$

\section{CONCLUSION}

Flyback with PD circuit micro-inverter for PV system is proposed. In this paper, a high-power decoupling with small ripple is achieved using PD circuit with small capacitance for dc input side. The stress of spike voltage on the main MOSFET is limited by recycle the leakage energy of the transformer and absorbed it during PD circuit without needing for additional a snubber circuit across the main MOSFET. For this reason, the large volume of micro-inverter is minimized with long lifetime, which lead to minimize the total cost of proposed micro-inverter. Utilization of the proposed micro-inverter realizes ac output current feeds to the grid with low THD $(2.7 \%)$ and unity P.F(0.99). Finally, this paper presents a new control scheme for a high-power decoupling technique, which can reduce the turn off losses and increase the efficiency as shown in simulation results.

\section{REFERENCES}

[1] T. Shimizu, K. Wada, and N. Nakamura, "Flyback-Type Single-Phase Utility Interactive Inverter with Power Pulsation Decoupling on the DC Input for an AC Photovoltaic Module System, "IEEE Trans. Power Electron., vol.21, no.5, pp.1264-1272, Sep.2006.

[2] H. Hu, S. Harb, N. Kutkut, I. Batarseh, and Z. John Shen, “ Decoupling Techniques for Micro-inverters in PV Systemsa Review," IEEE Energy conversion congress and Exposition, 12 Sep. 2010.

[3] S. Harb, Haibing Hu, N. Kutkut, I. Batarseh, and Z. John Shen, "A Three-port Photovoltaic (PV) Micro-inverter with Power Decoupling Capability," IEEE Applied Power Electronics Conference and Exposition (APEC), 2011 TwentySixth Annual, pp. 203-208, 6 Mar. 2011.

[4] Yanlin Li, and Ramesh Oruganti, "A Low Cost Flyback CCM Inverter for AC Module Application," IEEE Transactions on Power Electronics, vol., no.3, pp.1295-1303, Mar. 2012. 
[5] Young-Ho Kim, Jun-Gu Kim, Young-Hyok Ji, Chung-Yuen Won, and Tae-Won Lee, "Flyback Inverter using Voltage Sensorless MPPT for AC Module Systems," IEEE Power Electronics Conference (IPEC), pp. 948-953, 21 Jun. 2010.

[6] Anastasios Ch. Kyritsis, Nikolaos P. Papanikolaou, Emmanuel C. Tatakis and John C. Kobougias, "Design and Control of a Current Source Flyback Inverter for Decentralized Grid-connected Photovoltaic Systems," IEEE Power Electronics and Applications, 2005 European Conference, 11 Sep. 2005.

[7] Ching-Ming Lai, Ming-Ji Yang, and Wei-Chi Liu, "Parallel-Operated Single-Stage Flyback-Type Single-Phase Solar Micro-inverter," IEEE Intelligent Green Building and Smart Grid (IGBSG), International Conference, pp.1-5, 23 Apr. 2014.

[8] M. Gao, M. Chen, C. Zhang, Z. Qian, “Analysis and Implementation of An Improved Flyback Inverter for Photovoltaic AC Module Applications,” IEEE Transactions on Power Electronics, vol.29, no.7, pp.3428-3444, Jul.2014.

[9] Xiao-Fei He, Z. Zhang, and Xin Li., "An Optimal Control Method for Photovoltaic Grid-connected Interleaved Flyback Micro-inverters to Achieve High Efficiency in Wide Load Range," IEEE Power Electronics and Motion Control Conference (IPEMC), 7th International, 2 Jun. 2012.

[10] Young-Hyok Ji, Doo-Yong Jung, Jae-Hyung Kim, Chung-Yuen Won, and Dong-Sung Oh, "Dual Mode Switching Strategy of Flyback Inverter for Photovoltaic AC Modules, " IEEE Power Electronics Conference (IPEC) International, pp. 2924- 2929, 21 Jun. 2010.

[11] H. Watanabe, and Jun-ichi Itoh, "Isolated Single-phase AC Grid Connected Converter With small Inductors and Capacitors for Micro-inverters," IEEE Applied Power Electronics Conference and Exposition (APEC), pp.15421549, 8 Mar. 2017.

[12] T. Lodh, and V. Agarwal, "Single Stage Multi-Port Flyback Type Solar PV Module Integrated Micro-inverter with Battery Backup, " IEEE, in Power Electronics, Drives and Energy Systems (PEDES), 2016 International Conference on, pp. 1-6, 14 Dec. 2016.

[13] S. Sukatjasakul, and S. Po-Ngam, "The Micro-grid Connected Single-phase Photovoltaic Inverter With Simple MPPT Controller," IEEE, in Electrical Engineering Congress (IEECON), 2017 International, pp. 1-4, 8 Mar.2017.

[14] D. Ahmad, I. Saleh, and M. Miftahul Munir, "Design and Development of a Series-Configuration Mazzilli Zero Voltage Switching Flyback Converter as a High-Voltage Power Supply for Needleless Electrospinning,” Elsevier publisher, Procedia Engineering, Vol.170, pp.509-515, Jan.2017.

[15] J. Liao, J. Su, L. Chang, and J. Lai, "A Mixed Decoupling Power Method for Single-phase Grid-connected Inverters, " IEEE, in Power Electronics for Distributed Generation Systems (PEDG), 2016 IEEE 7th International Symposium on, pp. 1-5., 27 Jun. 2016.

[16] M. Satyanarayana and P. S. Kumar, “Analysis and Design of Solar Photovoltaic Grid Connected Inverter, ”Indonesian Journal of Electrical Engineering and Informatics (IJEEI), Vol.3,No.4, pp.199-208, Dec. 2015.

[17] A. H. Ali, H. S. Hamad and A. A. Abdulrazzaq, "Performance Investigation of Grid Connected Photovoltaic System Modeling Based on MATLAB Simulation," International Journal of Electrical and Computer Engineering (IJECE), Vol.8,No.6, pp. 4847-4854, Dec. 2018.

[18] M. R. B. Khan, J. Pasupuleti, J. Al-Fattah, and M. Tahmasebi, "Optimal Grid-connected PV System for a Campus Micro-grid," Indonesian Journal of Electrical Engineering and Computer Science, Vol.12,No.3, pp. 899-906, Dec. 2018. 